\title{
Editorial
}

International Archives of
Allergy
Immunology

\section{Allergen-Specific Tolerance Induction: Of Mice and Men}

\author{
Wolfgang Pfützner \\ Department of Dermatology and Allergology, Philipps University Marburg, Marburg, Germany
}

IgE-mediated respiratory allergies are among the most prevalent diseases in the Western world with about $25 \%$ of the European population suffering from allergic rhinoconjunctivitis and around 5\% affected by bronchial asthma [1]. While symptomatic therapies like nasal and inhalative corticosteroids or oral antihistamines show only temporal relief, allergen-specific immunotherapy (AIT) carries the potential of persistently reversing the natural course of these diseases. The first successful application dates back more than 100 years when patients suffering from hay fever showed substantial improvement of their allergic symptoms after receiving repeated subcutaneous injections of grass pollen extract [2]. Since then, many clinical studies with different allergens and forms of their application (e.g. subcutaneous or sublingual, ultra rush, slowly increasing or cluster dosing regimens) have proven the efficacy of AIT, both for treatment of allergic rhinoconjunctivitis [3, 4] and bronchial asthma [5], and in 1998 the WHO approved AIT as the only causative therapy for IgE-dependent allergies [6].

While the clinical effectiveness of AIT is well established, the immunological changes underlying the induction of allergen tolerance remain incompletely understood. Potential mechanisms encompass a switch from a Th2 to a Th1 cell-dominated immune reaction, the induction of regulatory $\mathrm{T}$ (Treg) cells, a simple loss of allergen-specific $\mathrm{T}$ cell responses and the production of IgG antibodies, which are able to block allergen binding by IgE [7-9]. However, it is still debated to what extent the different factors contribute to the development of aller- (c) 2015 S. Karger AG, Basel

$1018-2438 / 15 / 1662-0081 \$ 39.50 / 0$ gen tolerance. In this regard, animal models represent very helpful tools to analyze the immune effects of AIT in more detail since they allow investigators to focus on certain aspects when evaluating the immune mechanisms of tolerance induction, and can thus close a gap between in vitro analysis and immunological studies in humans [10].

A variety of mouse models have been developed to study the immune alterations of tolerance induction and one has to keep in mind that no model completely mimics the clinical and immunological features of the human situation $[11,12]$. Important parameters affecting the outcome are: (i) the mouse strain, (ii) the allergen (ovalbumin as an obligatory IgE-inducing allergen or clinically relevant antigens, like house dust mite or birch pollen allergen), (iii) the route of its administration (intraperitoneal, intranasal, intratracheal, subcutaneous, oral), (iv) the dosing regimen (low dose, high dose, escalating doses), (v) the type of adjuvants (alum, endotoxins, other or none) and (vi) the duration of treatment (e.g. rapid, gradual or intermediate desensitization protocols can result in very different immune alterations, albeit with similar clinical responses [13]). Furthermore, clinical and immunological relevance of the animal model has to be interpreted differently depending on the type of model, i.e. if it represents a prophylactic model preventing either allergen sensitization or the elicitation of allergic reactions in sensitized animals, or if it really induces allergen tolerance in sensitized mice which already have become allergic after subsequent allergen challenge [11]. While

\section{KARGER 125}

E-Mail karger@karger.com

www.karger.com/iaa
Correspondence to: Prof. Dr. Wolfgang Pfützner

Department of Dermatology and Allergology, Philipps University Marburg Baldingerstrasse

DE-35043 Marburg (Germany)

E-Mail wolfgang.pfuetzner@med.uni-marburg.de 
only the latter closely resembles the clinical situation of AIT-treated allergic patients, reports employing this model are rather rare.

In a previous issue of International Archives of Allergy and Immunology, van Rijt et al. [14] presented a mouse model which considers several typical features of AIT in humans. Mice with allergic airway hyperresponsiveness induced by a clinically relevant allergen (birch pollen) received AIT with the allergen extract adsorbed to alum and applied by subcutaneous injections on a weekly basis for a total of 2 months. While the efficacy of this AIT protocol was confirmed by inhalation of birch pollen aerosol, cellular analysis revealed that tolerance induction was accompanied by reduced allergen-specific $\mathrm{T}$ cell responses encompassing a variety of different cytokines (IL-4, IL-5, IL-13, IFN- $\gamma$, IL-10, IL-17A). On the other hand, a continued increase of birch pollen-specific IgG antibody production was noticed. Taken together, these findings suggest that important outcomes of AIT are: (i) a diminished allergen-specific $\mathrm{T}$ cell activation, which comprises several T cell subsets like Th2 and Th1, but also Treg and Th17 cells, and (ii) the induction of antibodies, which potentially block allergen-induced, IgE-mediated immune reactions [15].

When interpreting the results of this animal model, an important question is how they translate into the clinical situation, and in particular how these findings reflect the immunologic alterations induced by AIT in humans? Re- cent studies investigating allergic patients during AIT in very closely netted schedules revealed only a temporary (or even no significant) induction of IL-10-producing type-1 Treg (Tr1) cells and IFN- $\gamma$-secreting Th1 cells, whereas a general loss of allergen-specific $\mathrm{T}$ cell reactivity was observed as a long-term result, not only of the disease-specific Th2 cells, but also of suppressive $\operatorname{Tr} 1$ or Th2-counterbalancing Th1 cells [16-18]. Thus, the mouse model of van Rijt mirrors specific effects seen in AIT-treated patients who finally develop an immunological phenotype similar to nonallergic individuals, in whom the $\mathrm{T}$ cells are usually unresponsive to allergens and who do not necessarily show significantly increased numbers of Treg cells $[16,19]$.

Mouse models of allergen-specific tolerance induction resembling features of AIT in humans carry the potential for better understanding of the immune mechanisms of tolerance induction. For example, functional in vivo analysis could be performed in the van Rijs model helping to explain the loss of allergen-specific $\mathrm{T}$ cell reactivity, which could be due to allergen ignorance, T cell anergy [20], deletion [16] or inhibition mediated by allergen-blocking IgG antibodies [21]. Moreover, the impact of different forms or dosing schedules of AIT, which might lead to diverse immunological responses of allergen tolerance [13], could be further explored, thus shedding more light on how and why various applications of AIT work in humans.

\section{References}

1 Asher MI, Montefort S, Bjorksten B, Lai CK, Strachan DP, Weiland SK, Williams $H$ : Worldwide time trends in the prevalence of symptoms of asthma, allergic rhinoconjunctivitis, and eczema in childhood: ISAAC Phases One and Three repeat multicountry crosssectional surveys. Lancet 2006;368:733-743.

2 Noon L: Prophylactic inoculation against hay fever. Lancet 1911;i:1572-1573.

3 Calderon MA, Alves B, Jacobson M, Hurwitz B, Sheikh A, Durham S: Allergen injection immunotherapy for seasonal allergic rhinitis. Cochrane Database Syst Rev 2007:CD001936.

4 Radulovic S, Calderon MA, Wilson D, Durham S: Sublingual immunotherapy for allergic rhinitis. Cochrane Database Syst Rev 2010:CD002893.

5 Abramson MJ, Puy RM, Weiner JM: Injection allergen immunotherapy for asthma. Cochrane Database Syst Rev 2010:CD001186.

6 Bousquet J, Lockey R, Malling HJ: Allergen immunotherapy: therapeutic vaccines for al- lergic diseases: a WHO position paper. J Allergy Clin Immunol 1998;102:558-562.

7 Akdis M, Akdis CA: Mechanisms of allergenspecific immunotherapy: multiple suppressor factors at work in immune tolerance to allergens. J Allergy Clin Immunol 2014;133:621631.

8 Matsuoka T, Shamji MH, Durham SR: Allergen immunotherapy and tolerance. Allergol Int 2013;62:403-413.

9 Möbs C, Slotosch C, Löffler H, Pfützner W, Hertl M: Cellular and humoral mechanisms of immune tolerance in immediate-type allergy induced by specific immunotherapy. Int Arch Allergy Immunol 2008; 147:171178.

10 Renz H: How can animal models lead to improved specific immunotherapy (SIT)? Allergy $1999 ; 54: 39-40$.

11 Tournoy KG, van Hove C, Grooten J, Moerloose K, Brusselle GG, Joos GF: Animal models of allergen-induced tolerance in asthma: are T-reguatory-1 cells ( $\mathrm{Tr}-1$ ) the solution for T-helper- 2 cells (Th- 2 ) in asthma? Clin Exp Allergy 2006;36:8-20.

12 Kumar RK, Foster PS: Modeling allergic asthma in mice. Am J Respir Cell Mol Biol 2002; 27:267-272.

13 Fox EM, Torrero MN, Evans H, Mitre E: Immunologic characterization of 3 murine regimens of allergen-specific immunotherapy. J Allergy Clin Immunol 2014, Epub ahead of print.

14 van Rijt LS, Gouveia L, Logiantara A, Canbaz D, Opstelten DJ, van der Kleij HPM, van Ree R: Birch pollen immunotherapy in mice: inhibition of Th2 inflammation is not sufficient to decrease airway hyper-reactivity. Int Arch Allergy Immunol 2014;165:128-139.

15 Flicker S, Linhart B, Wild C, Wiedermann U, Valenta R: Passive immunization with allergen-specific IgG antibodies for treatment and prevention of allergy. Immunobiology 2013; 218:884-891. 
16 Wambre E, DeLong JH, James EA, TorresChinn N, Pfützner W, Möbs C, Durham SR, Till SJ, Robinson D, Kwok WW: Specific immunotherapy modifies allergen-specific $\mathrm{CD} 4^{+} \mathrm{T}$-cell responses in an epitope-dependent manner. J Allergy Clin Immunol 2014; 133:872-9.e7.

17 Möbs C, Ipsen H, Mayer L, Slotosch C, Petersen A, Würtzen PA, Hertl M, Pfützner W: Birch pollen immunotherapy results in longterm loss of Bet v 1-specific TH2 responses, transient TR1 activation, and synthesis of IgE-blocking antibodies. J Allergy Clin Immunol 2012;130:1108-1116.
18 Bohle B, Kinaciyan T, Gerstmayr M, Radakovics A, Jahn-Schmid B, Ebner C: Sublingual immunotherapy induces IL-10-producing $\mathrm{T}$ regulatory cells, allergen-specific $\mathrm{T}$-cell tolerance, and immune deviation. J Allergy Clin Immunol 2007;120:707-713.

19 Möbs C, Slotosch C, Löffler H, Jakob T, Hertl M, Pfützner W: Birch pollen immunotherapy leads to differential induction of regulatory $\mathrm{T}$ cells and delayed helper T cell immune deviation. J Immunol 2010;184:2194-2203.
20 Müller U, Akdis CA, Fricker M, Akdis M, Blesken T, Bettens F, Blaser K: Successful immunotherapy with T-cell epitope peptides of bee venom phospholipase A2 induces specific T-cell anergy in patients allergic to bee venom. J Allergy Clin Immunol 1998;101:747754.

21 Linhart B, Narayanan M, Focke-Tejkl M, Wrba F, Vrtala S, Valenta R: Prophylactic and therapeutic vaccination with carrier-bound Bet $\mathrm{v} 1$ peptides lacking allergen-specific $\mathrm{T}$ cell epitopes reduces Bet $v 1$-specific $T$ cell responses via blocking antibodies in a murine model for birch pollen allergy. Clin Exp Allergy $2013 ; 44: 278-287$. 